\title{
Attitudes Of Jordanian Students Toward Managers' Leadership Styles And Their Relationship To The National Culture
}

\author{
Moyaid Sulieman, Al-Ain University of Science and Technology, UAE
}

\begin{abstract}
This study explores the attitudes of a group of university students about managers' leadership styles and the cultural characteristics of the Jordanian society. The amount of research on the topic of leadership styles in Jordan is rare, particularly when associated with national culture. The outcomes demonstrated that the surveyed students were more disposed to portray the proposed leadership styles of managers as Team management style followed by Country Club style. On the other hand, when these students were asked to describe their national culture, they described it in a way similar to the Arab Group culture presented by Hofstede. Furthermore, the surveyed students gave power distance then muscularity the first confirmation. No significant relation observed between students' attitudes of leadership styles and characteristics of the Jordanian culture. Reasons for this outcome together with a few recommendations are incorporated into this study.
\end{abstract}

Keywords: Jordanian National Culture; Students' Attitude; Managers’ Leadership Styles

\section{INTRODUCTION}

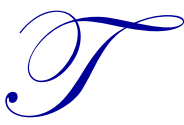

he concepts of national culture, organizational culture, and leadership style, have been central to plentiful studies in organizational behavior, sociology, anthropology, International management behavior and international business (Bellamy,2010). Many specialists have contended for a direct impact of national culture on leadership style. They claimed that leadership behavior is determined culturally and hence varies markedly from culture to culture (e.g. Burger and Bass1979; Muna,1980; Sulieman,1984; Hofstede, 1991; Ali,1993;1997; Randeree and Chaudhry, 2007). Hofstede, for example, contended that organizations are culture bound and that manager and organizations are not detachable from their original cultures. Eventually, every manager, somehow, has been shaped by his culture.

However, while the current research believes in the impact of national culture on managerial leadership behavior, it goes a step further to explore the relationship between students' attitude of managers' leadership styles and the features of their national culture. This study therefore, has four objectives. The first is to explore how management students, who have no previous work experience, perceive manager's leadership styles in their national culture. The second objective is to examine how these students describe their national culture. The third objective is to see whether there is a relationship between the managers' leadership characteristics as perceived and expected by these students and the characteristics of their national culture. This is important for Arab and International business in general and in particular, for academic staff working in management departments of Arab universities. Giving the scarcity of research in this area, knowledge of socio-cultural and work related values of leadership styles in Arab countries would be of great interest for international management investigators. Jordan is a promising nation for those who need to set up business in it. In recent years, the kingdom has started several policies that aimed at stimulating entrepreneurs to actively participate in the economic transformation and encouraging foreign direct investments. On the other hand, knowing how students think of and envision the conduct of managers in the real world will help academic staff building up their teaching methods and making administrative courses more productive for the students, and society at large. Finally, the fourth objective is to compare the results of the present study with those of Hofstede. 
The paper is organized as follows; the next section reviews the literature on national culture and its relationship to organizational culture and leadership styles. Following that the research methodology and research hypotheses are presented, and then the gathered data is analyzed. Finally, the research will end up with summary and recommendations.

\section{LITERATURE REVIEW}

\section{National Culture}

Culture is the soul of a society and the mark of its personality. It is a key column in the establishing of countries and their advancement. Every country has its own way of life from which it derives its components, elements and features, by which it is characterized and to which it belongs.

National culture depicts the common values and conventions from which the forms of thinking, feeling, and acting initiate in a society. National culture could be considered as the way of life which separates one society from another (Yahchouchi, 2009). According to Erez and Early (1993), individuals from the same society are more likely to interpret and assess situational events in a similar way than those from different societies. Hoecklin (1995) and Tayeb (1996) had practically the same perspectives as Hofstede. Hofestede (1980) argued that each individual conveys inside himself pattern of thinking, feeling and potential actions which were learnt all through his/her lifetime. He called these mental programs, "Culture" which he defined as "the collective programming of the mind which distinguishes the members of one group or category of people from another". Based on his very famous study, on IBM that covered 74 countries, Hofstede (2005) exhibited a model of national culture with five components; power distance, uncertainty avoidance, individualism, masculinity and future orientation, see table 1. Hofstede claims that these dimensions affected thinking and action in predictable ways.

Table 1. Hofstede's (2005) Five Components of Culture

\begin{tabular}{|c|c|}
\hline Power Distance & $\begin{array}{l}\text { Mirrors the degree to which the less powerful individuals in a culture expect and accept } \\
\text { that power is disseminated unevenly }\end{array}$ \\
\hline Individualism vs. Collectivism & $\begin{array}{l}\text { Mirrors the degree to which culture encourages persons as opposed to collectivist, } \\
\text { group -centered concerns. Individualism relates to societies in which the ties among } \\
\text { persons are unfastened. Collectivism relates to societies where persons are united into } \\
\text { solid and cohesive in-group. (p.76) }\end{array}$ \\
\hline Masculinity vs. Femininity & $\begin{array}{l}\text { A masculine society is a society in which the social genders roles are clearly } \\
\text { separating. A feminine society is the one in which the emotional gender roles overlap. } \\
\text { (p120) }\end{array}$ \\
\hline Uncertainty Avoidance & $\begin{array}{l}\text { The degree to which the members of a culture feel endangered by unclear or unknown } \\
\text { circumstances. (p.167). }\end{array}$ \\
\hline Long-term vs. Short-term Orientation & $\begin{array}{l}\text { The degree to which employees encourage long-run planning or short -run planning. } \\
\text { (p210) }\end{array}$ \\
\hline
\end{tabular}

These five measurements together can not be expected to deplete the universe of dissimilarities between national cultures, but they have important face - validity and have been observationally shown to be correlated to many sides of management practices. For example, power distance has been shown to be correlated with the approachability for subordinates of the boss; Individualism-collectivism with negotiation behavior and training courses; Uncertainty avoidance with job satisfaction; Masculinity - femininity with the percentage of female managers; and long versus short -term orientation with the propensity to save (Hofstede 2001)

Indeed, Hofstede's model is the most broadly cited operational definition and measures of national culture of any society.

In this setting, management researchers have showed that the Arab society has its own particular social and cultural environment, which plays a key role in exhibiting its organizational practices and managerial methods. In his original research, Hofstede (1980), using a scoring system for each dimension, he found Arab culture to have: 
- A high power-distance score of 80: Demonstrating unequal dispersion of influence and wealth.

- A high uncertainty avoidance score of 68: Showing Middle Easterner society's narrow mindedness towards instability.

- A low Individualism score of 38: Showing a solid slant towards groups or community that shows itself in solid family connections.

- An average Masculinity score of 52: Showing that variables other than national culture (e.g. religion) might be in charge of strong gender differences inside Arab society.

These results and their consequences have been reinforced by Nydell (1996), Parnell and Hatem (1999).

\section{Impact of National Culture on Organizational Culture}

Hofstede (2005) contends that national culture and organizational culture are dissimilar phenomena; He confirms that a national culture is learned in the initial years of our life while organizational culture is shallower and is learned when individuals are grown-ups. However, this does not infer that national culture does not impact the organizational culture. The impact of national culture on organizations has been studied from diverse sides, for instance, George, Jones and Gonzalez (1998) noticed that national culture impacts the employees' transaction procedure as well, because employees' attitude is molded by the features of their domestic culture. Likewise, Yousef (1998) records that administration styles diverge from culture to culture, which proposes that culture has an impact on the administration styles.In fact, national culture not merely influences organizational cultures and employee's behaviors, but it likewise affects our attitude towards understanding organizational culture. Hofstede (2005) states that:

Not only organizations are culture bound; theories about organizations are similarly culture bound. The professors who wrote the theories are children of a culture. Hofstede (2005) additionally explains that diverse national cultures influence organizational cultures differently. Cultures with individualistic beliefs have a different effect on organizational cultures than national cultures with collectivistic qualities. For instance, Hofstede (2005) confirms that organizations within individualistic cultures tend to accept that employees will act according to their own interests and match them with their employer's interest. Employees are not anticipated that would include their family connections at work, because such a concept is rejected in these organizations. Likewise, relationships between the organization and the worker are largely based on individual performance which likewise influences the rewards system. Failing to meet such legally binding relationship by having a poor performance is a legitimate and socially accepted reason to be ended from the organization. That means that the task is more imperative than the individual connections in individualistic cultures. Hofstede (2005) also remarks that organizations within collectivistic cultures will probably perceive and be affected by the group needs before settling on any choice. For instance, such organizations want to hire workers who are identified with individuals already working in the organizations because the individual is not seen freely, but rather as a man who has a place with a group. Organizations inside collectivistic cultures likewise design the inducements and rewards and other monetary prizes based on the group performance as opposed to individual performance. Moreover, the constructive personal relationship between the organization and the worker is essential for the worker to be recognized as an individual from the group. This positive relationship empowers in building up a life-time informal contract between the worker and the organization (Abdullah, et al, 2011). Along these lines, individual connections are expected to be more significant than the tasks in collectivistic culture. A summary of these differences is presented in Table 2.

Table 2. Individualism/Collectivism in Organizational Cultures

\begin{tabular}{|c|c|}
\hline Individualistic Organizational Cultures & Collectivistic Organizational Cultures \\
\hline $\begin{array}{l}\text { - Workers act for their personal interest that accompanies the } \\
\text { business interest. } \\
\text { - Using family connections inside the business is observed } \\
\text { negatively. } \\
\text { - Rewards are built on individual contributions. } \\
\text { - -Job is more important than individual connection. }\end{array}$ & $\begin{array}{l}\text { - Workers act for group benefits } \\
\text { - Family relations are used for the advantage of the } \\
\text { organization. } \\
\text { - Payments are built on group contributions. } \\
\text { - Individual relation is more important than the job }\end{array}$ \\
\hline
\end{tabular}

The mentioned differences are general themes that occur in these two different cultures. 


\section{Effect of National Culture on Leadership Style}

Researchers have contended that managerial conduct is socially determined and hence varies substantially from society to another (Muna,1980; Adler,2002). Many authors have proposed that national culture can influence leadership in more than one way. Managers are associated with the social values and the general behaviors of the societies they grew up in. They acquired overtime, appropriate and inappropriate types of conduct. Various cases exhibit how societal and organizational culture can shape the manager's and individual behavior. Frez and Early (1993) have likewise contended for the influence of society on the manager's and employees' behavior. They recommended that social standards shape the managers and employees psychological experience of self-identity and help generate the criteria that are used to assess a manager's performance. In a nation with moderately high power distance values (e.g. Iran), kids normally discover that the father is a definitive power in the family and they demonstrate solid appreciation and reverence to him. They discover that the father recognizes what is ideal and settles on choices for the benefit of the family. As a result, in such culture, managers tend to be more autocratic.

Interestingly, in nations with generally low power separation qualities, for example, Denmark, family choices are made with broad talk and civil argument inside the family with participation of kids. Therefore, participative authority style is the prevalent style.

\section{Leadership Styles in Arabian Culture}

Much research has concentrated on identifying leadership behaviors. There is no deficiency of writings on leadership style. A large number of research and books have been written on what it means, why it is essential, and what it takes to be successful. Leadership behavior embodies the total pattern of overt and covert leaders' actions as seen by workers. It embodies a regular blend of attitude, abilities, qualities and skills that are demonstrated in a person's conduct. Each style reflects implicitly or explicitly, a manager's beliefs about subordinates' capabilities (Theory X or Theory Y for example). Employee attitudes of leadership are all what really matters to them. Workers do not react merely to what leaders think and do and say, but to what they perceive leaders are. Leadership is truly in the eyes of the beholders.

Management researchers have shown that the Arab society has its peculiar social and cultural setting which plays a key role in molding its organizational procedures and managerial methods. (Sabri, 2004). In Hofstede's study (2005), there were seven Middle Eastern countries; Egypt, Iraq, Kuwait, Lebanon, Libya, Saudi Arabia and United Arab Emirates. Jordan excluded. Hofstede alluded to these nations as (Arab Group). These nations, according to his findings, are high on power distance, moderate uncertainty avoidance, high collectivist and moderate masculine / feminine society. High on power distance means Arab culture teaching family members (children) that the father is the definitive power and they should show solid admiration and respect to him. Youngsters discover that their father comprehends what is best and makes decisions for the benefit of the family. Family in the Middle East is the focal point of the society. The family is the key social unit and Arabs honor and respect their families. As a result, in such culture, managers tend to be more autocratic, more collectivist and uncertain avoidance.

A few specialists showed that the main thrusts that are associated to the study of management in the Arab world are language, history, Islam, traditional values and external forces. (Suleiman, 1980; Weir, 1995; and Ali, 1995). Barakat (1991), for example, recognized that Islam religion is the most vital aspect in the Middle Eastern Society. Middle Easterners are individuals who talk the Arabic dialect or plummet from Middle Easterner tribes. A large portion of the Middle Easterners lives in the Center East which reaches out from the Atlantic Sea, to the Arabian Gulf. Around 95\%of the Arabs are Muslims.

\section{Islam}

Islam is the predominant religion in the Middle Eastern Society. A number of writers have discussed and examined its impact on manager's and employee's behaviors, (e.g. Parnell and Hatem 1999; Yousef 2001; Common,2011).

Islam is a far-reaching religion covering social, political and military statutes and the devotion of the spirit and the ethical parts of individual conduct (El-Kot and Leat 2007; 181). The Islamic Work Ethics underline and inspire 
diligent work, trustworthiness, kindness, justice and equitable and impartial dissemination of wealth in society. They likewise energize the procurement of skills and technology and emphasize cooperation in work and consultation. Good social relations at work are likewise supported. Another feature of Islam is the idea that what's to come is best left to Allah, an inclination that the length of you live by the religious principles all will be well. Hickson and Pugh (1995), alluded to this assumption as a hidden fatalism. A man is urged to have good qualities and practices. A manager, thusly, is required to embrace a center way and build up an adjusted personality. It implies that a manager with an adjusted identity is one who is firm yet not fierce, indulgent but rather not frail, and liberal but rather not unrestrained.

Another characteristic is kindness. Kindness is a strength and in this way persons are required to be benevolent to other people, regardless of who are they. To be an effective individual, one needs to know one's weaknesses that can hurt the procedure of decision making. Determination of an issue relies on the decision-making ability. Accordingly, a manager must be sufficiently keen to utilize use his impact and not his authority in the decision-making process. It is uncommon to go over a person who never gets furious. However, outrage to the degree that it impacts the proficiency of a manager is equally not expected of him. To deal with the circumstance effectively, the manager must end up being a solid and able man, not something else (Ahmad, 1995).

Oversights will undoubtedly happen unless a man excludes himself from the class of individuals. In this way, in a hadith it is said, "Gain from your errors and do not rehash those errors." Likewise, to maintain a strategic distance from oversights a manager must be proficient. Once in a while, missteps are additionally made because of carelessness and lack of regard. Researchers are required for consultation. A man being is not faultless. There is a plausibility of settling on a wrong choice. Flexibility, along these lines, is expected to change and enhance the choice. Strategies intended to accomplish set targets can be overhauled once the result is acknowledged to not be right. So says a hadith, "Change the strategy when you are incorrect." (Ahmad, 1995).

\section{The Managerial Grid}

Managers might be worried for their employees and they likewise should have some sympathy toward the work to be done. The inquiry is, what amount of consideration would it be a good idea for them to pay to others? This is a model defined by Blake and Mouton in the mid-1960s. The current researcher believes that leaders' tendency to choose both sides is largely determined by many factors and the society culture is a profound factor in this regard.

The Leadership Grid Model is a behavioral model initially recognized five distinctive leadership styles based on the concern for individuals and the concern for production. Lately they added another two styles (the opportunistic and the paternalism styles). The ideal leadership style in this model depends on Theory Y. Here is a summary of these seven styles;

\section{The Impoverished Style $(1,1)$}

Leaders of this style have low sympathy toward both individuals and production. Leaders utilize this style to avoid getting into trouble. The principle sympathy toward the manager is not to be considered in charge of any mistakes, which results in less inventive decisions.

\section{The Country Club Style $(1,9)$}

This style has a high sympathy toward individuals and a low sympathy toward production. Managers utilizing this style give careful consideration to the security and comfort of the workers, in the hope that this would improve output. The subsequent atmosphere is generally amicable, but not necessarily that productive.

\section{The Produce or Perish Style $(9,1)$}

With a high sympathy toward production, and a low sympathy toward individuals, managers using this style discover worker needs are insignificant; they offer their workers cash in the hope to increase performance in return. Managers utilizing this style additionally force their workers through formal rules to accomplish the organization objectives. 


\section{The Middle-of-the-Road Style (5, 5)}

Managers utilizing this style attempt to adjust between organizational objectives and employees' needs. By giving some attention to individuals and output, managers hope to accomplish appropriate performance but doing as such gives away a bit of each concern so that neither production nor individuals needs are met.

\section{The Team Style $(9,9)$}

In this type of manager behavior, high concern is paid both to individuals and output. As recommended by Theory $\mathrm{Y}$, managers selecting this style support cooperation and commitment among workers. This strategy depends profoundly on making workers feel as a useful part of the organization.

\section{The Opportunistic Style (--)}

The opportunist style can utilize any other style in the Grid. The fortune hunter approaches each circumstance with the hidden demeanor of "What's in it for me?" and afterward tackles whatever style is most likely to bring about private point of interest. Opportunism stands out from every other Grid style because the expressed levels of concern shift as required to generate a persuading facade. The irregularity in the method utilized makes the style hard to recognize in the short term. Contingent upon the apparent point of preference, the opportunist may same to be solid and equipped for deriving others, defenseless and requiring direction, or politically oriented.

\section{The Paternalistic Style (++)}

The Paternalistic style results from two individual Framework styles, meeting up in a way that creates a one of a kind, joined style.

The two styles converge in the same association way that the two concerns do in the other Grid styles. Connections between the paternalist and co-workers resample those amongst guardian and youngster, where reward originates from the 1,9 impact to nurture, and punishment originates from the 9, 1 impact to direct practices. The resulting style is a man who orders activity and results by giving providing direction, praise, and remuneration and subtle reprimand.

The style selected relies on the individuals and circumstances confronted in conjunction with the potential gain perceived and every one of these variables relies on how you understand them in the light of national culture.

\section{RESEARCH PURPOSES AND PROBLEM}

\section{The Purpose}

The motivation behind this research is to give an in- depth understanding of manager's leadership behavior as perceived by university - management students in a society with broadly distinctive culture from Western social cultures. We want to know how these students portray their national culture. We, moreover, will contrast our results with those of other researchers notably the study of Hofstede. It is trusted that by so doing, this research will positively enhance Hofstede's study and administrative literature.

\section{Research Problem}

The researcher believes that there is strong impact of a given national culture on employees working in organizations inside that culture. That implies that the general qualities of the national culture have profound impact on how individuals see issues or circumstances that confronting them and how they resolve them. To that end, the present research is heading. It tries to investigate to what degree is there a relationship between students' attitudes toward their national culture's characteristics and the explanations they make of the behavior of managers who are working in the organizations found in that culture. Studies dealt with Arab manager's leadership styles and their connection to national culture are so rare. 


\section{Important of the Study}

A considerable research has been written on leadership behavior in business organizations, nevertheless, a few of these researches dealt with how university management students perceive the leadership style of the managers working in the organizations surrounding them as well as the characteristics of the national culture. This study, from this point, could be viewed uncommon as it tries to investigate the connection between these two sides and, at the meantime, tries to see if the outcomes acquired are reliable with different studies, particularly the Hofstede's study. Information would come from attitudes of management students would be utilized as the base for future, more comprehensive, research. Needless to say that the Jordanian society does excluded in Hofstede's research.

It is perceived that the pre-understanding of how management students see and depict managers' leadership behavior how would they spurring workers, decision-making, is of valuable advantage to academic staff and students. In terms of quality of education, understanding how students perceive manager's behavior and how they depict their national culture, will certainly advantage academic staff and help them expand the effective functioning of their teaching styles and curriculums. Society will likewise profit by reorienting these educational programs in the light of the mindset of the students and this will contribute in preparing students to be more equipped for confronting daily issues of their society.

\section{Research Questions}

This research is basically sought to find answers to the following main questions:

1. What is the dominant manager's leadership style according to the surveyed students?

2. What are the basic characteristics of the Jordanian culture?

3. Is there a positive correlation between the dominated styles that being perceived by students of management and the characteristics of Jordanian national culture?

4. To what degree are the obtained results of this study consistent with that of Hofstede and other studies?

\section{METHODOLOGY}

This study draws its methodology from two fundamental propositions in the reviewed literature. First, Hofstede's (1980) cultural bound which assumes the predominant effect of national culture on employees - managers behavior inside the organizations working in that culture; second, Blake and Mouton's seven leadership styles as portrayed in their leadership Grid (1964). Measurement of national culture; Hofstede's five dimensions of national culture were selected in this study.

\section{Present-Day Jordan}

Jordan is an Arab country in the southwest of Asia. It is a small country with limited natural resources and water comes first. Much of Jordan is covered by dessert. The official language is Arabic and the most population is Muslims. The population of Jordan is slightly over six million as of the year 2013. 95\% of Jordanian's population is Arabs, and the remaining are Circassians, Chechens, and Armenians. The family in the Middle East as we mentioned before is at the focal of the society and Jordan is no exception. The average number of typical family is 5.3 persons in 2004.Family members are close and care for each other. The father (or grandfather) has complete power over his family and more often the final word in any decision. As for the education sector, in 2006, there were 2787 government schools, 1493 private schools, 48 community colleges, and 28 state and private universities. Today, access to basic education in Jordan is emphasized in all the country's development plans. Jordan exports phosphate, potash, and many fertilizing products all over the world. Jordan is a very attractive place for foreign investments due to many reasons such as safety, political stability and its central location in the Middle East.

\section{Population and the Sample}

The population is all management students currently studying management sciences in Alzaytoonah University. Number of this population is around (500) students. The students taking part in this study are those who are enlisted and taught by the current researcher. The number of distributed questionnaires was (100), and received (80) 
completed copies. Every Student was asked for to answer two questionnaires at the meantime. The first managed the qualities of the Jordanian national culture and how students perceive them. Students were requested to respond to this questionnaire to a Likert 7- points' scale extending from (1-very highly present) to (7- very rarely present). With respect to the second questionnaire which had a place with Blake and Mouton Leadership Styles, likewise, respondents were requested that give their attitudes toward what sort of style the perceived manager would choose to handle the problem in hand. According to Blake and Mouton's Model, the components of leadership style are as per the following; Conflict resolution, initiative, gathering information, employees' direction, decision making and feedback. Here again a scale of 7-points used.

The aim of the second questionnaire was to investigate what kind of managerial styles these students have in their minds.

\section{RESULTS AND DISCUSSIONS}

In the following section the researcher will center discussions on three levels; the general level, which deals with the individual characteristics of the studied students in terms of gender, age, and year of study. On the second level, we will focus on the general characteristics of the Jordanian national culture as perceived by these students. In the third level, analysis will be concentrated on the association between Jordan national culture and the prevalent manager's styles. Lastly, a profound examination and remarks of the primary results will be presented.

\section{Personal Characteristics of the Students}

The general characteristics of the studied students are listed in the Table 3. As can be seen from the table, the majority of respondents are males $(58.2 \%)$, most of them are from the age group (17-20) (36.2\%), and age group $(21-25),(55.0 \%)$. Most respondents are studying Business Administration (60.0\%), and management information systems $(17.5 \%)$, and the majority are either in the third year of study $(25 \%)$ or fourth year $(41.5 \%)$.

Table 3. General Characteristics of the Studied Students

\begin{tabular}{l|c|c}
\hline \multicolumn{1}{|c}{ Characteristics } & Frequency & $\%$ \\
\hline Gender & 46 & 58.2 \\
\hline Male & 34 & 41.8 \\
\hline Female & & 36.2 \\
\hline Age Group & 29 & 55.0 \\
\hline $17-20$ & 44 & 8.8 \\
\hline $21-25$ & 07 & 60. \\
\hline $26-30$ & & 17.5 \\
\hline Field of Study & 48 & 6.2 \\
\hline Business Admin & 14 & 16.3 \\
\hline Information systems & 05 & 15.0 \\
\hline Financial Management & 13 & 18.8 \\
\hline Accountancy & & 25.0 \\
\hline Level of Study & 12 & 41.2 \\
\hline First Year & 15 & \\
\hline Second Year & 20 & \\
\hline Third Year & 33 & \\
\hline Forth Year & & \\
\hline
\end{tabular}

The following figures indicate that Jordan society is ranked high on power distance dimensions, the mean was (5.71) out if 7- points scale. It is also high on Masculinity dimension (4.64). 
As for both collectivist and uncertainty avoidance dimensions, they came almost moderate; both have the same means and standard deviations, (3.92) and (1.62). However, the lowest mean was for the future - oriented dimensions. See Table 4.

Table 4. Jordan National Culture Dimensions

\begin{tabular}{l|l|l|l}
\hline \multicolumn{1}{c|}{ Dimensions } & Mean & SD & Level \\
\hline Power Distance (PD) & 5.71 & 1.52 & High \\
\hline Masculinity & 4.64 & 1.51 & High \\
\hline Collectivist & 3.92 & 1.62 & Moderate \\
\hline Uncertainty Avoidance & 3.92 & 1.62 & Moderate \\
\hline Future Oriented & 3.71 & 1.71 & Semi-moderate \\
\hline
\end{tabular}

These results, especially the results of power distance and masculinity dimensions, give support to Hofstadter's study of the Arab group. In the event that we review his findings in such manner we would find that the examined Arab nations are described by the following: high power distance, moderate uncertainty avoidance high collectivist and moderate masculine society. The current results of this research are likewise steady with Sabri's results (2004). She discovered, for instance that the Jordanian national culture is high on power distance, moderate on uncertainty avoidance, more collectivist, and moderate on masculine culture.

The second section of the questionnaire (part B) asked about the most relevant leadership styles, managers are anticipated to utilize when confronting troublesome exercises in their everyday work. The original idea of these questions and activities are taking from Blake and Mouton Managerial Grid.

Table 5. Results Illustrating Prevailing Leadership Styles

\begin{tabular}{l|c|c}
\hline \multicolumn{1}{c}{ Leadership Styles } & Mean & SD \\
\hline Improvised (1.1) & 2.98 & 0.843 \\
\hline Team management (9.9) & 5.05 & 1.184 \\
\hline Middle of road (5.5) & 3.70 & 0.639 \\
\hline Produce (9.1) & 4.17 & 0.628 \\
\hline Country club (1.9) & 4.74 & 0.785 \\
\hline Opportunistic (- , -) & 4.14 & 0.767 \\
\hline Paternalistic (9+9) & 3.43 & 0.911 \\
\hline
\end{tabular}

As can be observed from table (5), the team management style is overwhelming in such manner where the mean was (5.05) with 1.184 deviation. The Secord style was country club style, and the third style was the produce style, with means and standard deviations (4.74), (4.17), (0.785), and (0.628) respectively. The lowest perceived style to be utilized by the Jordanians managers according to the images of these students was the impoverished style.

\section{Connection Between Jordan National Culture and The Prevalent Manager's Leadership Styles}

As it has been said before, and relying upon the previous studies done by different researchers of administration, the cultural dimensions of a given society influences not only the behaviors of the people, but also their thinking toward many things that may consistently happen in the workplace. That implies there is strong association between national culture and leadership style in the organizations of the same culture.

Our investigation demonstrated no significant correlation exists between culture characteristics and leadership styles. The relationship exists between national culture characteristics and prevailing leadership style is weak (O.114).

One reason that prompted this frail relationship is that these students have influenced by present day speculations and styles of leadership which they had learned during university years. 
They discovered that these styles are most gainful over the long run than whatever remains of the other leadership styles. In view of this point, the researcher encourages academics who are teaching in managements to teach students these theories and emphasize their necessity in practical life.

Utilizing this kind of leadership will contribute to alter the current cultural characteristics of the Jordanian society in the long run. As it will gradually transform the culture of the society from a culture emphasizes power distance between individuals to a culture of cooperation and emphasizes team work.

\section{CONCLUSION}

It has been recognized that the national culture of a given society is, to a great extent, deciding the general structure of the individuals' practices of that society. Success in achieving an organization's goals and objectives is relying upon the managers and their prevailing or predominating leadership styles.

In spite of the fact that we have seen a few styles depicted by the studied students, the predominating ones were team management style and, then, country club style. Such styles are normally the outcome of what these students have been taught and learned in their daily life and the management courses they have concentrated on.

The study lends some support to Homestead's and Sabri's studies in that the Jordanian culture is very much like whatever rests of Arab society. Jordan as an Arab society, Sabri (2004) wrote, likewise imparts fundamental social qualities to whatever is left of the Arab world, particularly those nations considered by Hofestede.

In a society described by high power distance, we expect that power is unequally disseminated among members of an organization. A manager is expected to accept greater power distance between organization members, collectivist in his orientation and to be uncertain avoidance.

In Jordan, as well as in other Arab countries, power orientation is practiced in the social, political and administrative structure. According to Sabri's conclusions, the Jordanians are known to be well-mannered, dutiful and respect authority. Indeed, this behavior lies on the tribal and patriarchal frameworks.

The current research also found that the Jordanians society is high in masculine dimension, and at the same time, moderately collectivist. In such cultures, administration is continually focusing on how gatherings could be overseen on the grounds that people connections beat assignment.

\section{AUTHOR BIOGRAPHY}

Moyaid Sulieman holds a Ph.D. degree in organizational behavior from Glasgow University in United Kingdom. Currently is a professor of strategic human resource management at Al-Ain University of science and Technology. His main interests include leadership style, organizational behavior, and strategic human resource management. Moyaid.Sulieman@aau.ac.ae

\section{REFERENCES}

A. Khaliq Ahmad (1995). "Islamic Values in Management of Change" KL:

Abdulla, Ikhlas A. and Al - Homoud, Moudi, A. (2001). "Exploring the implicit leadership theory in the Arabian Gulf states "Applies psychology; an international review, Vol. 50 No (4) pp 506 - 531.

Abdullah, ABM; Boyle, Stephen; and Johan, Carmen, (2001) Cultural Factors in Workforce Management; The case of multinational companies operating in Bangladesh. International Review of Business Research Papers, Vol. 7. No. 2. March 2011.pp196-211.

Adler, N. J. (2002), international dimensions of organizational behavior, 4th edition, south Western college publishing, Cincinnati, $\mathrm{OH}$.

Al - Faleh M (1987) "cultural influences on Arab management development "case study of Jordan "journal of management development "Vol. 6. No. 3. pp $19-33$

Ali, Abbas J. (1993) Decision - making style, individual and attitudes toward risk of Arab executives, international studies of management and organization, Vol. 23. No. (3) pp. $53-73$. 
Ali A. (1995) "Cultural discontinuity and Arab management thought "journal of,International studies of management and organization 25 (3), p $3-6$.

ellamy, Sheila (2010) Toward a Cultural Understanding of Academic Worlds. International Review of Business Research Papers.Vol.6. No. 5 October 2010. Pp.46-57.

Barakat, H. (1991). The Modern Arab Society; an experimental, social research (4th ed.), center for Arab unity studies, Beirut.

Blake, Robert Rogers, and Jane Srygley Mouton. The Managerial Grid: Key Orientations for Achieving Production through People. Gulf Publishing, 1964.

Common, Richard K. (2011) Barriers to Developing "leadership" in the Sultanate of Oman, International Journal of Leadership Studies, Vol. 6.No. 2,

El-Kot, G. and Leat, M. (2007) "Do Egyptian and Foreign Owned Organizations Adopt Similar HRM Practices in an Egyptian Context? "Arab Journal of Administration. Vol.27. No. (1). pp. 175-197.

Erez, M. \& Early, p. (1993), culture, self-identity, and work. New York, Oxford university press.

George, Jennifer M.; Jones Gareth R; Gonzalez, Jorge A. (1998) "The Role of affect in cross cultural Negotiation "journal of international business studies, Vol. 29, pp $749-772$.

Hofstede, G. (1980) culture's consequences: international differences in work - related values, London, sage publications.

Hofstede, G. (2000), Culture and Organizations, Software of the Mind, London, McGraw -Hill Book Co.

Muna, F.M. (1980) the Arab executive, London, McMillan.

Nydell, M. (1996), Understanding Arabs; A guide for Westerners. USA; International press

Parnell, J.A., and Hatm, T. (1999). Cultural Antecedents of Behavioral Differences between American and Egyptian Managers, Journal of Management Studies, 36.pp.399-418.

Randeree, k. and Chaudhry, A. (2007) "leadership in project managed environment; employee attitudes of leadership styles within infrastructure development in Dubai "international review of business research papers. Vol. 3 No. (4) October. pp 220- 232

Randeree.K. And Chaudhry, A., (2007).” Leadership in Project Managed Environment; Employee Attitudes of Leadership Styles within Infrastructure Development in Dubai,” International Review of Business Research Papers, Vol.3.No.4. October.pp.220-232.

Sabri, Hala M. (2004) socio - cultural values and organizational culture, journal of transnational management development. Vol. 9. No (2), 2004 pp. $123-145$.

Suleiman, M. (1984), Iraqi Mangers: their backgrounds and attitudes, Doctoral thesis Glasgow university.

Tayeb, M. (1996) organizations and national culture; methodology considered, organization studies, pp. 429 - 446

Weir, D.H., (1995)." The fourth Paradigm Revisited” A Paper presented at the Arab Management Conference, Bradford Management Center, Bradford, and July 4-6.

Wilson, R.W (1977). Deviance and social control in Chinese society, New York, prager.

Yahchoushi, Georges. (2009), Employees' Attitudes of Lebanese Managers' Leadership Styles and Organizational Commitment. International Journal of Leadership Studies, Vol. 4. No. 2, pp. 127-140.

Yousef D. A. (1998) correlates of perceived leadership style in a culturally mixes environment, leadership and organization development journal. Bradford, Vol.19. (7).

Yousef,D.A.(2001).Islamic Work Ethic; a Moderator Between Organizational Commitment and Job Satisfaction in Cross Cultural Context, Personnel Review, 30. pp.152-169. Management Times Mar 21, p 6. 


\section{NOTES}

